\title{
The Influence of Supervisor's Support and Protection Against Whistleblowing Decision in The Organizations of Local Government In Indonesia
}

\author{
PRIYASTIWI* \\ STIE Widya Wiwaha Yogyakarta \\ ABDUL HALIM \\ Universitas Gadjah Mada
}

\begin{abstract}
The purpose of this study is to empirically examine the influence of supervisor's support and protection against whistleblowing decision in the organizations of local government in Indonesia. Also, under a condition of superior support and protection, this study examines the effects of auditors' and nonauditor/employees' types of work in the organization of local governments towards the decision on whistleblowing the fraud. This research uses the experimental method to 48 students of Master of Accounting in a large state-owned university. By using fourcase scenarios, participants were asked to answer the possibility to whistleblow the fraud that occurred in a local government organization. The results of this research indicate that the employee would be courageous to whistleblow the fraud when they feel supported by their employers. The results also explain the importance of protection for whistleblowers. The results indicate that high protection is still required by the whistleblower to avoid the threat of any retaliation when the supervisor's support is low. Besides, the results reveal that, under the condition of high supervisor's support and protection, auditors would take a higher whistleblowing decision than non-auditors..
\end{abstract}

Keywords: supervisor support, protection, whistleblowing, local government

Intisari: Tujuan dari penelitian ini adalah untuk menguji secara empiris pengaruh dukungan atasan dan perlindungan terhadap keputusan whistleblowing di organisasi pemerintah daerah di Indonesia. Selain itu, di bawah kondisi dukungan dan perlindungan yang kuat, penelitian ini juga menguji pengaruh jenis pekerjaan auditor dan non-auditor/karyawan dalam organisasi pemerintah daerah terhadap keputusan tentang pengungkap fakta penipuan. Penelitian ini menggunakan metode eksperimen untuk 48 mahasiswa Magister Akuntansi di sebuah perguruan tinggi negeri besar. Dengan menggunakan empat kasus skenario, peserta diminta untuk menjawab kemungkinan untuk mengungkap penipuan yang terjadi di organisasi pemerintah lokal. Hasil penelitian ini menunjukkan bahwa karyawan akan berani untuk mengungkap penipuan ketika mereka merasa didukung oleh majikan mereka. Hasilnya juga menjelaskan pentingnya perlindungan bagi pelapor. Hal ini

*Coresponding Author : priyastiwi@yahoo.co.id 
menunjukkan bahwa perlindungan yang kuat masih diperlukan oleh whistleblower untuk menghindari ancaman pembalasan ketika dukungan supervisor rendah. Selain itu, hasil menunjukkan bahwa, di bawah kondisi dukungan dan perlindungan supervisor yang kuat, auditor akan mengambil keputusan whistleblowing lebih tinggi daripada non-auditor.

Kata Kunci: dukungan supervisor, perlindungan, whistleblowing, pemerintah daerah

\section{Introduction}

Disclosures by the members of the organization about immoral and unlawful practices to persons or institutions that may influence the action are called a whistleblowing (Miceli, 2004). By these disclosures, errors can be immediately identified and corrected, thereby increasing efficiency, increasing employee morale, and potentially avoiding the negative reputation and financial consequences of lawsuits. Thus, there is considerable social value in understanding the whistleblowing process (Near \& Miceli, 2008).

One form of fraud is a fraudulent financial statement that can be reported through a whistleblower hotline. Vadera et al. (2009) find that the type of fraud and seriousness level of fraud affect a person to report it. Robinson et al. (2012) also examine that the type of fraud committed affects employee decisions to report. Providing the information by people within the organization plays an essential role in solving the problem of fraud because whistleblowers can easily access information about errors without any great effort (Burke \& Cooper, 2013).

The Association of Certified Fraud Examiners (ACFE, 2012) defines fraud as intentional misuse of personal enrichment. ACFE (2012) categorizes the cheating in three groups as follows: 1) Financial statement fraud, defined as fraud committed by management in the form of financial statements material misstatement. 2) Asset misappropriation and fraudulent disbursement. 3) Corruption, divided into a conflict of interests, bribery, illegal gratuity, and economic extortion. Lee \& Fargher (2013) argues that some of these frauds can sometimes be found by whistleblowing process.

Whistleblowing research is more prevalent in the private sector than in governmental organizations (Mesmer-Magnus \& Viswesvaran, 2005). This issue is 
becoming the concern in research because corporate frauds lead for 5\% losses more than worldwide organizational income (Dworkin, 2007). Whistleblowing can also be seen in government organizations (Cho \& Song, 2015). Rothschild (2013) asserts that whistleblowing can lead to substantial change and reformation in government organizations. While from a quantitative perspective, governmental organizations have a higher percentage of reporting errors than the private sector. Vadera et al. (2009) suggest that whistleblowing is a complex process. Therefore, the organizational characteristics can help to understand the reported unethical practices. Similarly, Valentine et al. (2006) suggest that to achieve the objectives of an ethics program, it depends on the organizational context. It is possible that there is a fraud that needs to be revealed in the governmental organizations.

Fraud in government organizations is different from private organizations. The type of fraud that occurs in the governmental organizations is in the form of corruption. Corruption in Indonesian governmental organizations refers to the UU TPK No. 31 of 1999. In Article 2 paragraph (1), it is stated that corruption is any person who unlawfully commits enrichment of himself or others or a corporation that may harm the financial or the state economy, paragraph (2) made in certain circumstances. The concept of fraud used in this research is a corruption according to UU TPK No. 31 in 1999 because corruption in governmental organizations could harm the state's finances and the state's economy.

In governmental organizations, corruption proportionally occurs in many local governments. This is evident from the KPK data from 2004 to May 2016 which indicate that regents or mayors who have been entangled in KPK cases are accounted as many as 56 people. Based on KPK data above, the handling of corruption that occurred in local government institutions was ranked as the 2nd largest case (acch.kpk.go.id). Nevertheless, fraud disclosure research in governmental organizations is still rare. The results also show a complex antecedent affecting the disclosure of the fraud. Indonesia Corruption Watch (ICW) also releases the findings that the most corruptive person during the year 2015 is a civil servant in the local government (Pemda) (Beritasatu.com, Sunday, February 7, 2016). 
Whistleblowing research is primarily focused on three factors that influence reporting: (a) individual factors, such as demographics, personality, age, gender, moral development (Vadera et al., 2009; Chiu, 2003); (b) situational factors, such as the moral intensity, the seriousness of the error, the degree of ambiguity of the error, the relative low whistleblower position of the offender (c) such as organizational size and structure, internal disclosure policies, codes of ethics, compensation systems, and organizational culture and climate (Chen \& Lai, 2014; Dasgupta \& Kesharwani, 2010; Katz et al., 2012). The understanding of the process is complicated by the complexity of the variables and the interactions between them (Sims \& Keenan, 1998). Therefore, further research requires the identification of the interactions of the factors affecting whistleblowing so that whistleblowing is effective.

There are gaps in the literature and the results of whistleblowing studies that are still unclear. Current research emphasizes more on individual factors that influence whistleblowing decisions (Vandekerkhove, 2010). However, the influence of organizational factors on the whistleblowing process is more important. This is because the organization has control over the working environment rather than individual values or moral development. Vandekerkhove (2010) states that current research overlooks an essential aspect of whistleblowing management. Research is trapped in the focus of the whistleblower and not on the process of handling the problem. This has led to the need for research that concentrates on an effective whistleblowing process rather than examining the individual factors who conduct whistleblowing.

One crucial factor which affects the disclosure of fraud is the organizational factor. Taylor and Curtis (2013) argue that the impact of organizational variables such as the interaction between organizational response and power distance affects the likelihood of auditors to report (via hotline) about the deviant behavior. Also, Valentin et al. (2006) also state that organizational support is related to ethical decisions within the organization. Previous research suggests that support from top management and superiors can predict whistleblowing (Dworkin \& Baucus, 1998; Keenan, 2000; Sims $\&$ Keenan, 1998). A high level of organizational support will encourage employees to 
act on behalf of the organization by reporting errors that occur through internal channels.

Seifert et al. (2010) apply organizational justice theory to design whistleblowing policies and procedures. As a prosocial behavior, whistleblowing tends to increase when organizational procedures are the result of an exchange with superiors who are considered fair. The results show that policies and mechanisms incorporate the levels of procedural justice, distributive justice, and higher interactional justice will increase the likelihood that internal accountants will report fraudulent financial statements. In interactional justice, it focuses on the quality of interpersonal treatment that is received by the employees from superiors when organizational procedures are implemented (Bies \& Moag, 1986). Interactional justice has an interpersonal component that reflects the extent to which individuals are treated with dignity and respect by superiors who can determine outcomes, obtain information, and make decisions (Greenberg, 1990; Scott et al., 2007). Perception of interactional justice is made up of interpersonal exchanges between managers and subordinates. Informal interaction between whistleblowers and management can sometimes damage formal processes (Miceli \& Near, 1992; Near et al., 1993). For example, the threat of retaliation from superiors may be considered by the employees who will conduct whistleblowing (Mesmer-Magnus \& Viswevaran, 2005; Miceli \& Near, 1992; Miceli et al., 2008). Fair interaction is resulted from the treatment of the supervisor to the whistleblower by not making threats of retaliation (Miceli \& Near, 1992; Miceli et al., 2008). Mesmer-Magnus and Viswevaran (2005) also argue that perceived support from supervisors plays a role in whistleblowing decisions.

Also, error observers who doubt the integrity and management ability to prevent errors can result in a very high personal risk, thus, they decide to remain silent (Gundlach et al., 2003; Henik 2008, Near et al., 2004). Keil et al. (2010) report that the perceived benefits of whistleblowing increase when trust in supervisors increased, which in turn was associated with higher levels of whistleblowing.

This research is based on the theory of social exchange between employees and superiors as a complement to the theory of justice. Employees will disclose if there is 
supervisor support. Employees form a perception of the extent to which the supervisor appreciate their contributions and care about their well-being or called as perceived supervisor support (PSS) support (Kottke $\&$ Sharafinski, 1988). The supervisor acts as an organizational agent in managing subordinates. The supervisor is very appreciated by the organization and playing a role in realizing the character of the organization (Roadhes \& Eisenberger, 2002). Employee perceptions of the status given to the superiors by the organization provide confidence that the support of superiors is also the support of the organization.

The organization has provided support by establishing and promoting the use of anonymous whistleblower hotline (Bedard et al., 2008; Curtis and Taylor, 2009). Unfortunately, the survey consistently showed that a large number of employees who realized the error chose not to report (Miceli et al., 2008). The main reason is the fact that the individual is afraid of receiving retaliation as a consequence of reporting the observed error. One example is life and career will be damaged as a result of reprisals (Brickey 2003; Ramirez 2007; Bowen et al., 2010). Specifically, Miceli and Near (2002) report that whistleblowers tend to receive any retaliation if the top management or supervisors maintain the errors and retaliate to whistleblowers. It is evident that the contextual variables are associated with reprisals including from senior management, direct supervisors, and co-workers, as well as an organizational climate for whistleblowing. Lack of support from supervisors and senior management leads to retaliation of whistleblowers (Near and Miceli, 1986).

In order to help ease the fear of retaliation and encourage reporting, ACFE (2012) recommends that organizations should emphasize anti-retaliation protection to the employees (e.g., protection from harassment, loosing of employment or promotion, and/or retaliation forms), other than confidentiality and anonymity in the whistleblower hotline policy (Mesmer-Magmus \& Vismesvaran, 2005). Protection from retaliation is essential because of the risks faced by whistleblowers, even when there is anonymity provision. Anonymity often does not guarantee the confidentiality of the whistleblower because during the investigation evidence is needed that may identify the whistleblowers and lead them to be exposed to the risk of retaliation 
(Fasterling \& Lewis 2014). Protection from any forms of retaliation received by the whistleblowers in hotline policies will reduce employee fears, which will motivate employees to report via hotline compared to the absence of protection.

Several studies have shown that anti-retaliation laws are largely ineffective in motivating whistleblowing (Dworkin, 2007; Dworkin \& Near, 1997; Miceli et al., 2008). The legal experts argue that the specific protection is afforded by the Act for whistleblowers, has a relatively narrow range and is far from reality (Dworkin, 2007; Miceli et al., 2008). Also, the focus of this research is on organizational policies and management behaviors that can influence employee decisions to disclose fraud. The study based on the assumption that when an organization establishes a formal internal channel and provides protection, employees will be more daring to report mistakes (Moberly, 2006).

This study aims to test empirically the influence of superior support and protection toward whistleblowing decisions on local governmental organizations using experimental methods based on the theory of social exchange. Based on the theory of social reactance, this study also examines the effect of auditor and non-auditor types of work in local government organizations on whistleblowing decisions.

This research is expected to contribute to the development of the theory of whistleblowing by explaining the support of superiors and protections which affect the whistleblowing decisions namely the implementation of social exchange theory and social reactance theory. This research is expected to also contribute to the design of whistleblowing procedures that are effective in disclosing the financial fraud to government organizations in Indonesia.

The remainder of this paper is as follows: we provide a theoretical framework and development of hypotheses, followed by the method, and the analysis and results. We conclude with a discussion of our findings, recommendations, study limitations, and suggestions for future research. 


\section{Theoretical Framework and Development of Hypotheses}

\subsection{Theory of Social Exchange}

The theory of social exchange or social exchange theory explains the relationship between employees, and their organizations are an exchange of relations (Eisenberger et al., 1986). The employee is willing to work in an organization because the employee will redeem his business and loyalty with certain benefits. Eisenberger et al. (1986) state that employees perceive work as a form of exchange with their needs, so they always assess the organization which has concerned with the business that has been donated in return. In other words, employees who have extra work, expect organizations to provide a balanced reward. Employees also assess whether their socio-emotional needs, such as the need for recognition and respect are also met (Aselage and Eisenberger, 2003). Eisenberger et al. (1986) explain that organizational support is built by organizational treatments received by employees, such as in honorarium payments, promotion, trust, and participation in organizational policymaking. Employee assessment of the organization is also done by considering the frequency, seriousness, and sincerity of the organization in providing awards and recognition of the results of their operations (Eisenberger et al., 1990; Eisenberger et al., 1997). The awards which are given to organizational awareness will have a more significant impact on organizational support than the external pressure, such as union pressure or regulation (Rhoades and Eisenberger, 2002).

In the theory of social exchange, a person who has received a specific advantage will have a sense of obligation to repay what he has received (Eisenberger et al., 1986). The actions taken by the employee are viewed as the feedback for the actions of the organization. Management behaviors and organizational policies are the basis for employees to interpret organizational support. For employees, organizational support reflects how far which the leaders are committed to their interests. Bell and Menguc (2002) argue that there is an influence of the organizational support for contextual performance that includes various OCB (Organizational Citizenship Behavior) behaviors, such as helping others or defending the organization toward its 
goals. Other studies have also reported a direct positive effect between POS (Perceive Organizational Support) and OCB (Masterson et al., 2000).

\subsection{Psychological Reactance Theory}

The literature on social psychology shows the opposite effect of social pressures. The theory of psychological reactance (Brehm 1966, Brehm \& Brehm 1981) suggests that the attempts to persuade individuals to act in some way are often counterproductive, as this threatens the individual freedom. According to this perspective, individuals who are pressed to act in a certain way, perceive their freedom behavior to be reduced.

A whistleblower can also be a fraudster in the organization. Following the social pressure theory, someone does something which is not by a personal desire, but because there is social pressure (Dezoort \& Lord, 1997). In the theory of social pressure in accounting, DeZoort and Lord (1997) distinguish three forms of social pressure, namely 1) Compliance pressure on the explicit demand of individuals at any level. 2) Obedience pressure which refers to the pressure to obey the authorities. 3) Conformity pressure which refers to the pressure of group members. Acts that deviate from members of the organization, often occur because of the social pressure. Hartman and Maas (2010) research show that Business Unit controllers are faced with a dilemma about the interests of their units by deliberately creating budget slack. The creation of this slack, one of which is influenced by pressure from Business Unit managers. However, Davis et al. (2006) suggest that management accountants are more likely to make budget slack when they face the pressure of obedience directly from the supervisor. This result confirms earlier findings in psychological and auditing literature that social pressures induce individual conformity to avoid the negative consequences arising from a deviation from the group or being unfaithful to a higher authority (Lord \& DeZoort, 1997).

In a governmental organization, a person commits an illegal and immoral act, perhaps not because of personal motivation, but possibly because of the social pressure of the group or the head of the organization. According to the theory of 
psychological reactance, pressure can lead to psychological reactance occurring when freedom is eliminated or threatened with elimination (Brehm \& Brehm, 1981). Reactance considers unpleasant circumstances, which is composed of emotional components (e.g., feelings of anger) and cognitive components (e.g., resistance to authority, Rains, 2013). Reactance also requires behavior which tends to reject unlawful behavior (Brehm, 1966).

\subsection{Supervisor Support}

Employees develop a common view that supervisors contribute to their wellbeing (Kottke \& Sharafinski, 1988). Because supervisors act as organizational agents, they have a responsibility to lead and evaluate subordinate performance. Employees see superiors act in their favor as an indication of organizational support (Eisenberger et al., 2002). Also, employees understand that the superior's evaluation of the subordinates is often informed to the top management, which ultimately contributes to the superior support relationship with employee performance. Support from superiors has also been assessed regarding performance measurements involving a leadermember exchanges and supervisor's considerations.

Most of the theories explain organizational relationships with the belief of the employees that employees see their supervisor as an organizational agent. For example, the psychological contract theory (Rousseau, 1989, 1998) which assumes that employees assume the promises of superiors as the promise from the organization (Eisenberger et al., 2002; Eisenberger et al., 1986). Therefore, employees generalize their exchange relationships with superiors as an exchange for the organization because they see the supervisor as an organizational representative. Eisenberger et al. (2010) state that employees form a perception of the similarity between the supervisor and the organization as the embodiment of the supervisory organization (SOE / Supervisor Organizational Embodiment) (Eisenberger et al., 2010). The bigger the SOE, the higher the employees may feel that the superior's treatment is the treatment by the organization. Similarly, Near and Miceli (1996) found that lack of support from supervisors and top management will decrease the whistleblowing. An ethical leader 
will support and encourage ethical behavior, so it can motivate employees to uncover mistakes (Bhal \& Dadhich, 2011).

H1: Supervisor support positively affects fraudulent disclosure decisions.

\subsection{Protection}

The Association of Certified Fraud Examiners (ACFE, 2012) finds that whistleblowing is the most common method of detecting fraud. The whistleblower has managed to uncover 43 percent of all reported fraud (Cho \& Song, 2015). The auditor has a vital role in detecting fraudulent financial reporting through an adequate whistleblower hotline. Sometimes, however, the auditor accepts the damaging consequences of the client's company reputation which is being audited. Chaney and Philipich (2002) find that Andersen's clients experienced significant negative cumulative abnormal returns, after the announcement that the company had been involved in Enron's shredding documents inspection. Subsequently, clients of public accounting firms experienced abnormal negative returns about the disclosure of activities associated with failed audits (Ramirez 2007). Individuals may fear that they will suffer from job retaliation as a consequence of reporting. Consequently, it is not surprising that previous studies identified a strong negative relationship between the fear of retaliation and the intention to report the error (Mesmer-Magnus \& Viswesvaran 2005).

Some previous studies have examined the use of whistleblower hotline in the context of public accountants (Mesmer-Magnus \& Viswesvaran 2005, Curtis \& Taylor, 2009). Most studies have examined the impact of the whistleblower anonymity provision and the choice of external reporting outlets on the decision to reveal the error. For example, Curtis and Taylor (2009) survey auditors and find that participants have a less willingness to report unethical behavior when their identities might be disclosed. Meanwhile, Robertson at al. (2011) finds that auditors prefer to report anonymously when the fraudster has a bad reputation, but prefer to report using a non-anonymous outlet when the fraudster has a good reputation. 
Kaplan et al. (2009) specifically examined the effect of hotline security power on whistleblower reporting. The previous researchers found that participants are significantly less likely to report errors when the anonymous whistleblower protection policies are strong (e.g., the hotline was managed by a third or external party, as well as that the information is maintained in a tightly controlled secret environment). This research predicts that the higher the security level of the whistleblower hotline, the higher the probability of a whistleblower to report an error. The results suggest that whistleblowers are more likely to report through internal hotlines and without any information control. The results of Kaplan et al. (2009) state that whistleblowers are unwilling to report to the third parties. The whistleblowing hotline policy description may have been enough to create confidence in the anonymous reporting channel. Therefore, low protection in a whistleblower hotline policy can harm people who commit fraud disclosure.

One way to reduce the fear of retaliation and to increase employees' willingness to report, the organization has included the types of protection in the whistleblower hotline policy (Wainberg \& Perreault, 2016). That is, in spite of providing reporting channels, confidentiality and anonymity, an organization also includes special forms of protection from retaliation (such as harassment, loss of job, loss of promotion, decline in professionalism, and punishment, and financial consequences). ACFE (2012) recommends protection towards the retaliation to be offered to employees. A recent survey by Hassink et al. (2007) and Lee and Fargher (2013) suggest that many organizations now choose to include protection in the organization's whistleblowing policy manual.

H2: Protection has a positive effect on fraud disclosure decisions.

In the theory of organizational support, there is the possibility that employees may have a different view that employers as representatives of the organization. Employees see the supervisor not only as an organizational agent but also as a standalone individual, with different characteristics from the organization. Therefore, an employee will see the supervisor that is aligned with the organization or less in line 
with the organization. The variation in alignment of the supervisor with the organization can help to explain how far the variations affect the organizational commitment (Eisenberger et al., 2010). If the supervisor acts in a way that is different from the organization's strategic goals, then the employee also has a lower perceive about the characteristics of the supervisor with the organization. Therefore, employees will feel that the support of superiors is not the same as the support of the organization, because superiors have personality characteristics that show independent behavior which is independent of the organization. For example, new technologies adopted by the organizations often fail to be promoted by the management because supervisors consider the technology to have a little benefit (Davis, 1989). Also, supervisors believe that the implementation of technology will involve in a steep learning curve and not worth with the effort spent (Magni \& Pennarola, 2008). These conditions cause employees to have a low commitment to the organization because they feel that they are not supported by superiors.

When a whistleblower feels unsupported by an internal party, they will use an external channel to report a violation (Dasgupta \& Kesharwani, 2010). Whistleblowers who report errors through external channels, they are more likely to receive retaliation which may be worse rather than when the internal channels are used (Near \& Miceli, 1986). The use of external channels is more likely to acquire retaliatory behavior, as it violates the strength and structure of authority within the organization. Similarly, whistleblowers who fail to use anonymous channels during the whistleblowing process are more likely to receive retaliation (Miceli \& Near, 1994).

Specifically, Miceli et al. (2008) report that the effectiveness of whistleblowers tends to get any retaliation unless the supervisor or top management could retain retaliation to the reporter. The internal whistleblower becomes effective (whistleblowing to the parties within the organization or through a secret hotline), by providing an ethical procedure to stop cheating. This action can lead a benefit and keep the company's reputation (Miceli et al., 2008). Internal disclosure policies typically identify employees' responsibility to disclose errors to the certain parties within the organization. Employees can make internal disclosures through appropriate 
communication channels, formal investigation procedures, and protection guarantees for employees who have good intentions to disclose errors (Teo \& Caspersz, 2011).

H3: Under conditions of supervisor's support is low, and high protection will have a positive effect on fraud disclosure decisions.

\subsection{Type of work}

A whistleblower is often used to refer someone who seeks to uncover dishonesty and errors that occur within the organization. A whistleblower is an employee or auditor who tries to stop errors that may be hidden within the organization (Rothschild, 2008., Cassematis \& Wortley, 2013; Vadera et al., 2009). The management accountant or the financial officer may participate in fraud because of a pressure placed by a superior or co-worker. This pressure generates reactance, which aims to re-establish a sense of freedom and personal responsibility for the chosen decision. Individuals experience a reactance to reject the requested behavior, and often decide to act the other way (Brehm \& Brehm 1981). Pressure from managers to deviate from professional guidelines causes individuals to firmly oppose such behavior and put on their new role as professional and independent. In the case of fraudulent behavior, there is a possibility, and the fraudster turns to report because of their reaction to social pressure so that the management accountant will have a higher responsibility to report fraud than the auditor.

H4: Under conditions of supervisor's support is low; high protection will have a higher positive effect on fraudulent disclosure decisions by non-auditors than auditors.

\section{Research Methods}

\subsection{Sample and Data Collection}

Participants in this research are students of Accounting Magister Program in a Faculty of Economics and Business of a large state-owned university in the academic year of 2015. Total participants are calculated as many as 48 people. The participants work in governmental organizations, namely the Ministry of Finance of 20 students 
(41.7\%), BPKP 8 students (16.7\%), regency/city government 16 students (33\%), and the remaining four students $(8.9 \%)$ from other departments in Indonesia. Participants are selected in positions because they know about the fraud that occurs in the local government. Participants are invited voluntarily to follow this experiment. In total 56 students were participating in this research. The students come from 2 parallel classes who follow the course of Regional Finance Management. One student who did not complete the experimental instrument and seven students failed manipulation, so the total number of participants was 48 people. The demographic data of participants can be seen in table 1. Male participants are as much as $58.3 \%$, and $41.7 \%$ are women. Participants aged 30 to 40 years were $70.8 \%$, while those who aged above 40 years were only $2.1 \%$. Participants work experience is in between 5 to 10 years of $66.7 \%$, while less than five years as much as $22.9 \%$. Participants who work as government auditors' amount to 22 people (45.8\%). While $54.2 \%$ work as a non-auditor who work in the financial department at their institution.

\subsection{Experimental Procedure}

The experimental process was carried out with an experimental laboratory. Experimenter distributes the experiment materials randomly. The randomization test results show that there is no difference from the demographics for each cell. The case material is designed based on paper and pencil and consists of instructions, case sketches, and demographic questionnaires. Sketches of error include manipulation in the procurement process of goods/ services, deviation of procurement procedures, for example, the provisions of goods auctioned refers to the brand, not on the quality and specifications, the pricing of its estimates, the determination of the winning bidder. This is due to this mode that often occurs in local governmental organizations. The participants were given by manipulation of high and low supervisor's support, and high and low protection. The case sketch is illustrated with short sentences and drawings which make it easier for participants to remember and understand. The experimental instrument has been tested on the students six times until the participants can pass the manipulation check. At the end of the case, participants were asked to 
answer two questions that were used to check participants' understanding of cases given on a scale of 1-10. The participant who answered correctly was less than the average of the participants' answers, so they were excluded from the analysis.

Table 1.

Descriptive Statistics of the Participants

\begin{tabular}{|c|c|c|c|c|c|}
\hline Demography & $\mathrm{N}=48$ & Percentage & $\begin{array}{c}\text { Mean } \\
\text { WB }\end{array}$ & Std & $\underset{\text { (t-test) }}{\text { Sig. }}$ \\
\hline Gender & & & & & 0,952 \\
\hline Female & 20 & $41,7 \%$ & 6,0000 & 2,10263 & \\
\hline Male & 28 & $58,3 \%$ & 5,9286 & 2,52291 & \\
\hline Age & & & & & 0,207 \\
\hline$<30$ years old & 13 & $27,1 \%$ & 6,0000 & 2,04124 & \\
\hline $30-40$ years old & 34 & $70,8 \%$ & 5,8235 & 2,39280 & \\
\hline$>40$ years old & 1 & $2,1 \%$ & 10,0000 & & . \\
\hline Job Types & & & & & 0,789 \\
\hline Auditor & 22 & $45,8 \%$ & 5,8182 & 2,19602 & \\
\hline Non-Auditor & 26 & $54,2 \%$ & 6,0769 & 2,48069 & \\
\hline Experience & & & & & 0,589 \\
\hline$<5$ years & 11 & $22,9 \%$ & 6,4545 & 2,11488 & \\
\hline $5 \mathrm{~s} / \mathrm{d} 10$ years & 32 & $66,7 \%$ & 5,9063 & 2,50624 & \\
\hline$>10$ years & 5 & $10,4 \%$ & 5,2000 & 1,64317 & \\
\hline
\end{tabular}

\subsection{Measurement}

The hypotheses were tested with $2 \times 2 \times 2$ factorial experimental between-subject design that consists of (1) superior support and (2) protection (3) job types: auditor and non-auditor. The sketches are presented in a third person focus to minimize selfreporting bias, and the subject is measured from the likelihood that the first and third person focus will report a fraud. Experiments using case sketches to manipulate the variables superior's support and protection consistently (Mesmer-Magnus \& 
Viswesvaran, 2005; Miceli et al., 2008). While the measurement is done on the variable of types of job for auditors and non-auditors.

\subsection{Independent Variables}

The independent variables consist of a supervisor's support, protection, and job types: auditor and non-auditor. Supervisor's support is when the supervisor treats others with respect, courtesy, and respect, and trusts the correct information and explanation. Therefore, superior's support is operationalized by the supervisor's behaviors to the subordinates with attention, support, trust, and respect for potential whistleblowers (Eisenberg et al., 2002). Interaction with management is described as two things: a high-level support which highlights attention, trust, support, and high respect, while low-level support is a threatening attitude to the whistleblowers, distrustful, ignoring the information provided by the whistleblowers.

Protection is demonstrated by protecting employees from retaliation for disclosures that employees commit following the Witness and Victim Protection Law No. 13 of 2006. Under the Witness and Victim Protection Law (2006), whistleblowers are persons who provide information to law enforcement regarding the occurrence of a criminal offense. Protection includes protection from threats, self-security, family, and property, and there is no lawsuit against the whistleblowers. High protection is shown that the whistleblowers get all the security guarantees. While low protection is the whistleblowers does not get such protection, but only the guarantee related to the matter in court.

\subsection{Dependent Variables}

The dependent variable is the participant's decision to conduct whistleblowing. To measure this variable, the average of the participants' assessment is: (1) the participants; and (2) others, will report cheating using a secret hotline in each scenario. This research asks questions in 2 forms that are for himself and others. This is because previous research shows a social desirability bias. Social desire bias allows participants to try to appear more positive than their decision. 


\subsection{Control Variables}

Employee demographic characteristics are used as the control variables to exclude alternatives explaining the relationship between organizational support and protection with whistleblowing decisions. These characteristics include age, education, gender, experience. Besides, there are also control variables for situational factors, such as cheating types. Table 1 shows that there is no significant differences in age, education, and experience in fraud disclosure decisions. All participants argue that cheating types do not differ significantly with an average score of 8.175. Meanwhile, to test the social desirability bias, the difference between the participants' answers in deciding the disclosure of fraud is compared with the response if the sketch is answered from a third person's perspective (Lowe et al., 2015). The result is no difference between the two types of questions.

\subsection{Check Manipulation}

The check for manipulation is conducted to test the participants in understanding the concepts of cheating, supervisor's support, and protection which categorized under high or low conditions. The participants are asked to answer a check manipulation question with an answer scale from 1 to $10(1=$ very low to $10=$ very high $)$. Participants were given two questions for the cheating rate indicating a high fraud rate. The answer to the cheating sketch is considered correct if the participants answer above average. While check manipulation for the variables of the supervisor's support and protection, each also consists of 2 questions. For high support and high protection sketches, answers are considered to be true if more than average of 5.39 and 5.77. While sketches of supervisor's support and protection are low, then the correct answer is below the average of 3.98 and 3.86. The results of the analysis showed that participants who passed the manipulation amounted to 48 students.

\section{Results of Analysis and Discussion}

This research investigates the supervisor's support, and protection can influence the disclosure decisions that occur in local government organizations. Hypothesis 1 
predicts the effect of supervisor's support on fraud disclosure decisions. In Table 2, it shows the results of the $\mathrm{H} 1$ test, which the main effect of supervisor's support shows the value of $\mathrm{F}(1.429)=10.025, \mathrm{p}<0.003$. Higher supervisor's support results in a higher average of fraud reporting probability $(\mathrm{M}=6.708)$ than support for low $(\mathrm{M}=$ 5.208). This result supports H1. This indicates that the whistleblowing process will be high if there is a good interaction between the whistleblowers and the supervisors. Because the whistleblowing process is prosocial behavior, so if the whistleblowers are responded and trusted by the boss, then the whistleblowers will be more courageous to reveal the error.

Hypothesis 2 predicts the effect of protection on the decision of fraud disclosure, $\mathrm{H} 2$ test results the main effect of protection $\mathrm{F}(1,429)=37,904, \mathrm{p}<0,000$. High protection results in higher average probability of fraud reporting $(M=7,417)$ compared to low protection $(\mathrm{M}=4,500)$. The results support $\mathrm{H} 2$. Based on the theory of social exchange, whistleblowers do not expect rewards from the organization, but they report because they want to help the organization. Whistleblower expects that he can be free from retaliatory behavior. This is evident, if they are given by high protection, it will be more courageous to disclose the errors that exist in the organization.

For hypothesis 3, the ANOVA model analysis results show the interaction between the supervisor's support and protection toward the fraud disclosure decision, which indicates $\mathrm{F}(1.429)=3.094, \mathrm{p}<0.086$. The interaction results show that the interaction of the supervisor's support and protection is significant at $\alpha=0.10$. The results show that at a low support level, high protection will result in a high fraud disclosure decision ( $M=6,250)$, than if protection is low (4.1667). Results moderately support H3. Figure 1 shows that in low support, high protection will result in a higher decision than low protection, while on high support also the same. This means protection will strengthen the whistleblower to uncover fraud if supervisors support is low. The higher the support of supervisors and the higher the protection will motivate employees to make fraud disclosure. It can be concluded that protection is a variable 
that moderates the influence of supervisor's support to the decision of fraud disclosure.

\section{Table 2}

Results of ANOVA test

Dependent Variable: WhistleBlow

\begin{tabular}{|l|r|r|r|r|r|}
\hline Source & $\begin{array}{c}\text { Type III Sum of } \\
\text { Squares }\end{array}$ & df & Mean Square & F & \multicolumn{1}{c|}{ Sig. } \\
\hline Corrected Model & $137,417^{\mathrm{a}}$ & 3 & 45,806 & 17,008 &, 000 \\
Intercept & 1704,083 & 1 & 1704,083 & 632,740 &, 000 \\
Support & 27,000 & 1 & 27,000 & 10,025 &, 003 \\
Protection & 102,083 & 1 & 102,083 & 37,904 &, 000 \\
Support * Protection & 8,333 & 1 & 8,333 & 3,094 &, 086 \\
Support * Protection & 145,849 & 3 & 20,836 & 7,572 &, 000 \\
Job & 118,500 & 40 & 2,693 & & \\
Error & 1960,000 & 48 & & & \\
Total & 255,917 & 47 & & & \\
Corrected Total & & & & & \\
\hline
\end{tabular}

a. R Squared = ,537 (Adjusted R Squared $=, 505$ )

Picture 1.

Interaction Result between Supervisor's Support and Protection

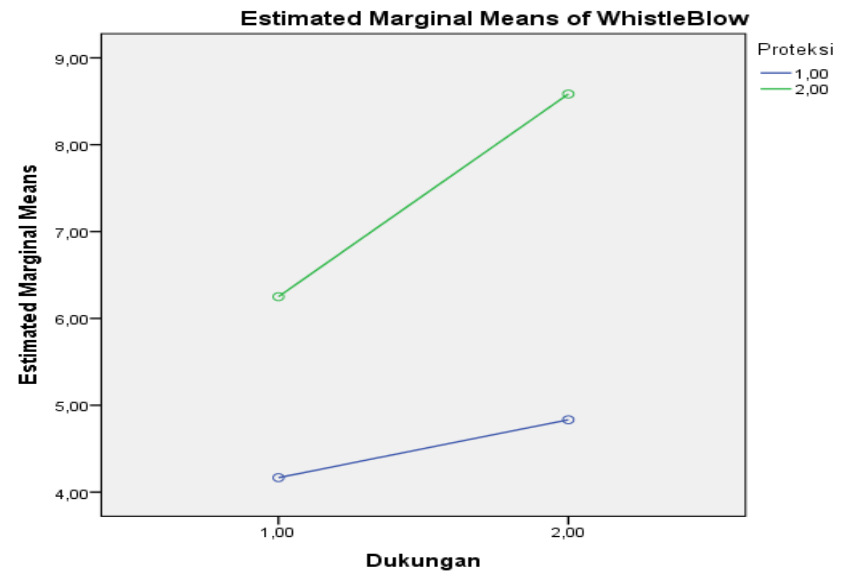

To test hypothesis 4 , is there any difference between the types of job that are auditor and non-auditor in whistleblowing decision because support of supervisors and 
protection, the analysis used is ANOVA three-way interaction. Results of interaction testing of supervisor's support, protection, and type of work are significant at p-value $<0,000$. Figures 2 and 3 show a comparison of the decisions on conditions of the supervisor's support of low and high support. Auditors will be higher in whistleblowing decisions when there is a high supervisor's support and high protection $(\mathrm{M}=8,800)$ than non-auditor $(\mathrm{M}=8.42)$. However, the test results show that non-auditors disclose higher fraud disclosures when supervisor's support is low, but high protection $(M=7.00)$ than auditors $(M=5.50)$. This expands Seifert's (2010) research on the interaction of interactional justice and distributive justice variables for the internal position of auditors or management accounting. Internal auditors will result in high internal whistleblowing if interactional justice and distributive justice are high. For management accountants, distributive justice does not affect whistleblowing decisions, when interactional justice is high. As a prosocial behavior, this study shows that high support results in high decisions, when given high protection, not because of the rewards. In Seifert (2010) research in high or low distributive justice conditions, non-auditors result in higher disclosure decisions than auditors when interactional justice is low. The study explains that under the conditions of superior support, non-auditors will result in higher whistleblowing decisions, due to high protection $(M=7.00)$ than auditors $(M=5.50)$, thus supporting hypothesis 4 .

Picture 2

Interaction Result Between Protection and Type Job at Low Supervisor's Support

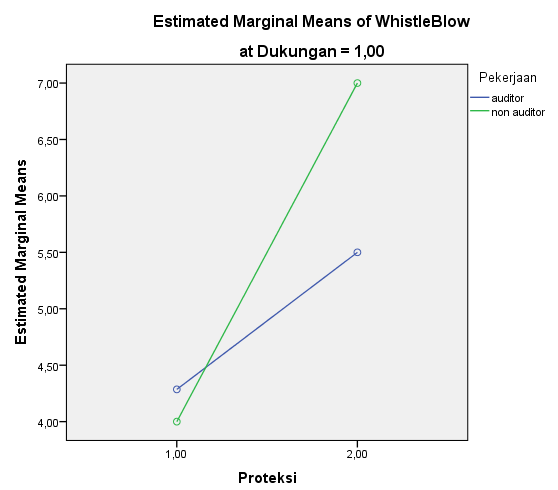

Picture 3

Interaction Result Between Protection and Type Job at High Supervisor's Support

5.

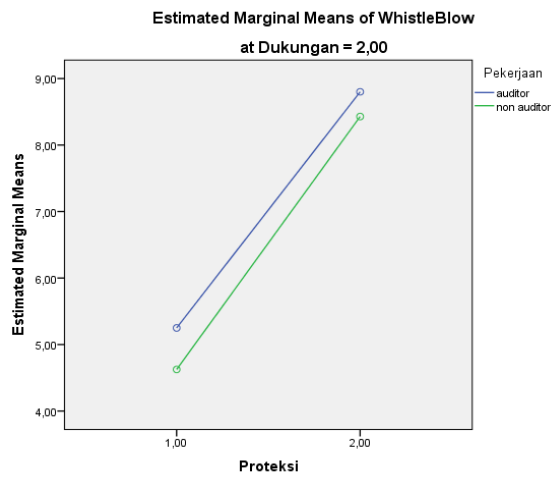




\section{Conclusion, Limitations, and Implications}

The study aims to explain the organizational factors that influence disclosure of fraud in local government organizations. This research is significant because this research explains the disclosure as prosocial behavior. As a prosocial behavior, whistleblowers make no effort to get any reward, as they reveal frauds that occur in local governmental organizations, but because of the reciprocal factors between employees and organizations, including supervisors. Employees will dare to decide to report any fraud when they feel supported by their supervisors. This research extends the findings of previous studies which suggest that a supervisor's support influences disclosure decisions (Mesmer-Magnus \& Viswesvaran, 2005) and explains interactional justice (Seifert, 2010).

The results of this research also explain the importance of protection for whistleblowers. The results showed that high protection is still required by the whistleblower to avoid the threat of retaliation. With an assumption that the disclosure of fraud is based on the theory of social exchange, then whistleblowers have demonstrated organizational citizenship behavior by protecting the organization from behaviors that undermine the organization and degrade people's confidence in the organization. As the organization rewards the whistleblowers, they must be protected from any threats and intimidation, including threats from supervisors. The results show that although supervisor's support is low, if protection is high, then the possibility of a whistleblower will reveal high the fraud is high. This research results in opposite results from previous studies of the weakness of the anti-retaliation model (Moberly, 2006). This study states that protection against whistleblower remains essential, so protection is expected following established rules and implemented in actual practice. This is a form of response from the organization by following up on fraud disclosure reports and providing protection against whistleblowers. The results of the organizational responses in the previous period will be used as factors that encourage to uncover fraud in the next period (Taylor and Curtis, 2009).

The results state that under a high supervisor's support and high protection, auditors make a higher disclosure decision than non-auditors. However, when support 
level is low, high protection leads non-auditors to make disclosure decisions higher than auditors. This is because of the high supervisor's support, then the existing employees in the organization have a higher responsibility because of social exchanges with supervisors. Also, based on the theory of social reactance, non-auditor employees who may previously know or participate in making errors, then they will be more courageous to disclose the fraud that is in the organization because they feel responsible for correcting errors that exist in the organization.

This study has a contribution which explains that organizational factors can encourage the disclosure of the fraud. In previous research, many studies have described the effects of individual factors, such as gender, ethical orientation, moral intensity, locus of control, experience and profession which affect the disclosure of fraud (Bhal \& Daachick, 2011; Chiu, 2003; Curtis \& Taylor, 2009; Miceli et al., 2012). If within the organization there are individuals who have characteristics as mentioned in the previous research, then the organization can encourage the individual in disclosing the fraud. Based on the theory of social exchange, this study provides evidence that a supervisor's support and protection can encourage disclosure decisions. Also, in the organization, there are also people who want to be free and maintain their professionalism. This is indicated by them who are doing an opposite reaction when they are pressured to cheat.

This research has several weaknesses that may affect the research results. This is due to the determinant of disclosure of fraud as a complex and interrelated process between one variable with other variables. Firstly, contextual factors that may also affect disclosure decisions have not been considered, such as organizational climate. Second, in whistleblowing decisions, there are two possible different things: the intention to reveal and the actual disclosure made by whistleblowers. This research does not distinguish between the two. Thirdly, in the non-auditor category in this study, it is not explained by the position of participants in the organization. However, because the participants are students with an accounting education background, it is assumed that they understand the financial statements that exist in the organization. 
This research provides implications that the practice in policy design and disclosure procedures require high protection on the whistleblowers. The protection provided is not only limited to regulations but also implemented in practice. While the suggestions for further research are: First, research can include the moderate variable that is culture or organizational climate. Secondly, further research may furtherly examine the reporting parties who may participate in organizational fraud (justice collaborator), so with this position, there is any chance that they will report the fraud. Thirdly, in this research, the disclosure of fraud is more internal, the next study can consider reporting to an external party.

\section{References}

Acch.kpk.go.id (2016). Penanganan Tindak Pidana Korupsi Berdasarkan Instansi tahun 2004-2016 (per Mei 2016). Diakses dari http://acch.kpk.go.id/berdasarkan-instansi, accessed 10 July 2016.

Aselage, J., \& Eisenberger, R. (2003). Perceived organizational support and psychological contracts: A theoretical integration. Journal of organizational Behavior, 24, 491-509.

Association of Certified Fraud Examiners (ACFE). (2012). Report to the Nations on Occupational Fraud and Abuse. Austin, TX: ACFE.

Bedard, J. C., D. R. Dies, M. B. Curtis, and J. G. Jenkins. (2008). Risk monitoring and control in audit firms: A research synthesis. Auditing: A Journal of Practice \& Theory 27 (1), $187-218$.

Beritasatu.com. (2016). ICW sebut pelaku korupsi terbanyak dari pejabat pemda. 7 Februari. Diakses dari http://www.beritasatu.com/nasional/347873-icw-sebut-pelaku-korupsiterbanyak-dari-pejabat-pemda.html, accessed 10 July 2016.

Bell, S. J., \& Menguc, B. (2002). The employee-organization relationship, organizational citizenship behaviors, and superior service quality. Journal of Retailing, 78, 131-146.

Bhal, K., \& Dadhich, A. (2011). Impact of ethical leadership and leader-member exchange on whistleblowing: The moderating impact of the moral intensity of the issue. Journal of Business Ethics, 103, 485-496.

Bies, R., \& Moag, J. (1986). Interactional justice: Communication criteria of fairness. In R. Lewicki, B. Sheppard, \& M. Bazerman (Eds.). Research on negotiations in organizations (Vol. 1). Greenwich, CT: JAI Press.

Brehm, J. W. (1966). A Theory of Psychological Reactance. New York, NY: Academic Press. 
Brehm, and S. S. Brehm. (1981). Psychological Reactance: A Theory of Freedom and Control. New York, NY: Academic Press.

Bowen, R. M., Call, A. C., \& Rajgopal, S. (2010). Whistle-blowing: Target firm characteristics and economic consequences. The Accounting Review 85, 1239-1271.

Brickey, K. F. (2003). From Enron to WorldCom and Beyond: Life and crime after SarbanesOxley. Washington University Law Review 81 (2), 357-401.

Burke, R. J., \& Cooper, C. L. (Eds.) (2013). Voice and whistleblowing in organizations: Overcoming fear, fostering courage and unleashing candour. Cheltenham, UK: Edward Elgar

Chaney, P. K., and K. L. Philipich. (2002). Shredded reputation: The cost of audit failure. Journal of Accounting Research 40 (4), 1221- 1245.

Chen, C.-P., \& Lai, C.-T. (2014). To blow or not to blow the whistle: the effects of potential harm, social pressure and organisational commitment on whistleblowing intention and behaviour. Business Ethics: A European Review, 23(3), 327-342. doi: 10.1111/beer.12053

Chiu, R. K. (2003), Ethical judgment and whistleblowing intention: examining the moderating role of locus of control, Journal of Business Ethics 43, 65-74.

Cho, Y. J., \& Song, H. J. (2015). Determinants of whistleblowing within government agencies. Public Personnel Management, 44 (4), 450-472. doi: 10.1177/0275074013515299

Curtis, M., and E. Taylor. (2009). Whistleblowing in public accounting: Influence of identify disclosure, situational context, and personal characteristics. Accounting and the Public Interest, 9 (1), 191-220.

Dasgupta, S., \& Kesharwani, A. (2010). Whistleblowing: A Survey of Literature. IUP Journal of Corporate Governance, 9 (4), 57-70.

Davis, F. D. (1989). Perceived usefulness, perceived ease of use, and user acceptance of information technology. MIS Quarterly, 13, 319-340.

Davis, S., F. T. DeZoort, and L. S. Kopp. (2006). The effect of obedience pressure and perceived responsibility on management accountants' creation of budgetary slack. Behavioral Research in Accounting 18, 19-35.

DeZoort, F. T., and A. T. Lord. (1997). A review and synthesis of pressure effects research in accounting. Journal of Accounting Literature 16, 28-85

Dworkin, \& Baucus. (1998). Internal vs. external whistleblowers: A comparison of whistleblowing processes. Journal of Business Ethics, 17(12), 1281-1298. doi: 1210.1023/A:1005916210589. 
Dworkin, T., \& Near, J. (1997). A better statutory approach to whistleblowing. Business Ethics Quarterly, 7, 1-16.

Dworkin, T. M. (2007). SOX and whistleblowing. Michigan Law Review, 105(8), 1757-1780.

Eisenberger, R.; Cummings, J.; Armeli, S.; and Lynch, P (1997). Perceived organizational support, discretionary treatment, and job satisfaction. Journal of Applied Psychology, 82 (5), 812-820

Eisenberger, R.; Fasolo, P.; and Davis La-Mastro, V. (1990). Perceived organizational support and employee diligence, commitment, and innovation. Journal of Applied Psychology, 75 (1), 51-59

Eisenberger, R.; Huntington, R.; Hutchison, S.; and Sowa, D. (1986). Perceived organizational support. Journal of Applied Psychology, 71 (3): 500-507

Eisenberger, R.; Stinglhamber, F; Vandenberghe, C.; Sucharski, I.L.; and Rhoades, L. (2002). Perceived supervisor support: employee retention. Journal of Applied Psychology, 87 (3), 565-571.

Eisenberger, R., Karagonlar, G., Stinglhamber, F., Neves, P., Becker, T. E., Gonzalez-Morales, M. G., \& Steiger-Mueller, M. (2010). Leader-Member Exchange and Affective Organizational Commitment: The Contribution of Supervisor's Organizational Embodiment. Journal of Applied Psychology. 16, 1-20. doi: 10.1037/a0020858

Fasterling, B., and D. Lewis. (2014). Leaks, legislation, and freedom of speech: How can the law effectively promote public-interest whistleblowing? International Labour Review 153 (1), 71-92.

Frank G. H. Hartmann and Victor S. Maas (2010). Why Business Unit Controllers Create Budget Slack: Involvement in Management, Social Pressure, and Machiavellianism. Behavioral Research In Accounting Vol. 22, No. 2, 27-49/

Greenberg, J. (1990). Employee theft as a reaction to underpayment inequity: The hidden cost of pay cuts. Journal of Applied Psychology, 75, 561-568.

Gundlach, M. J., S. C. Douglas, and M. J. Martinko. (2003). The Decision to Blow the Whistle: A Social Information Processing Framework. Academy of Management Review 28(1), 107-123.

Hassink, H., M. de Vries, and L. Bollen. (2007). A content analysis of whistleblowing policies of leading European companies. Journal of Business Ethics 75 (1), 25-44.

Henik, E. (2008). Mad as hell or scared stiff? The effects of value conflict and emotions on potential whistle-blowers. Journal of Business Ethics, 80, 111-119.

Kaplan, R. L., K. Pany, J. A. Samuels, and J. Zhang. (2009). An examination of the effects of procedural safeguards on intentions to anonymously report fraud. Auditing: A Journal of Practice \& Theory 28 (2), 273-288. 
Katz, M., LaVan, H., \& Lopez, Y. P. (2012). Whistleblowing in organizations: implications from litigation. S.A.M. Advanced Management Journal, 77(3), 4-17.

Keenan. (2000). Blowing the whistle on less serious forms of fraud: a study of executives and managers. Employee Responsibilities and Rights Journal, 12(4), 199-217. doi: 110.1023/A:1022820210577.

Keil, M., Tiwana, A., Sainsbury, R. and Sneha, S. (2010). Toward a theory of whistleblowing intentions: a benefit-to-cost differential perspective. Decision Sciences 41 (4), 787-812.

Kottke, J. L., \& Sharafinski, C. E. (1988). Measuring perceived supervisory and organizational support. Educational and Psychological Measurement, 48, 1075-1079.

Lee, G., \& Fargher, N. (2013). Companies' use of whistle-blowing to detect fraud: an examination of corporate whistle-blowing policies. Journal of Business Ethics, 114(2), 283-295. doi: 10.1007/s10551-012-1348-9

MacNab, B.R. and Worthley, R. (2008), Self-efficacy as an interpersonal predictor for internal whistleblowing: a US and Canada examination, Journal of Business Ethics 79, 407-421.

Magni, M., \& Pennarola, F. (2008). Intra-organizational relationships and technology acceptance. International Journal of Information Management, 28, 517-523.

Masterson, S. S., Lewis, K., Goldman, B. M., \& Taylor, M. S. (2000). Integrating justice and social exchange: The differing effects of fair procedures and treatment on work relationships. Academy of Management Journal, 43, 738-748.

Mesmer-Magnus, J. R., \& Viswesvaran, C. (2005). Whistleblowing in organizations: an examination of correlates of whistleblowing intentions, actions, and retaliation. Journal of Business Ethics, 62(3), 277-297. doi: 210.1007/s10551-10005-10849-10551.

Miceli, M. P. (2004). Whistle-blowing research and the insider: lessons learned and yet to be learned. Journal of Management Inquiry, 13(4), 364-366. doi: $310.1177 / 1056492604270801$.

Miceli, M. P., and J. P. Near. (1992). Blowing the Whistle: The Organizational and Legal Implications for Companies and Employees, New York: Lexington.

Miceli, M. P., and J. P. Near. (1994). Relationship among value congruence, perceived victimization, and retaliation against whistleblowers. Journal of Management 20(4): 773794.

Miceli, M. P., and J. P. Near. (2002). What Makes Whistle-Blowers Effective? Three Field Studies. Human Relations 55(4), 455-479.

Miceli, M. P., J. P. Near, and T. Dworkin. (2008). Whistle-Blowing in Organizations. New York, NY: Taylor-Francis. 
Miceli, M. P., J. P. Near, M. T. Rehg, and J. R. Van Scotter. (2012). Predicting employee reactions to perceived organizational wrongdoing: Demoralization, justice, proactive personality, and whistleblowing. Human Relations 65, 923-954.

Moberly, R. E. (2006). Sarbanes-Oxley's structural model to encourage corporate whistleblowers. Brigham Young University Law Review, 5(1), 1107-1180.

Near, J., Dworkin, T., \& Miceli, M. (1993). Explaining the whistle-blowing process: Suggestions from power theory and justice theory. Organizational Science, 4, 393-411.

Near, J. P. and M. P. Miceli. (1986). Retaliation against Whistle Blowers: Predictors and Effects. Journal of Applied Psychology 71(1), 137-145.

Near, J. P., \& Miceli, M. P. (1996). Whistle-blowing: myth and reality. Journal of Management Inquiry, 22(3), 507-526. doi: 10.1177/014920639602200306

Near, J. P., \& Miceli, M. P. (2008). Wrongdoing, whistle-blowing, and retaliation in the U.S. government: what have researchers learned from the Merit Systems Protection Board (MSPB) survey results? Review of Public Personnel Administration, 28(3), 263-281. doi: 210.1177/0734371X08319153.

Near, J.P., Rehg, M.T., Van Scotter, J.R. and Miceli, M.P. (2004). Does the type of wrongdoing affect the whistle-blowing process. Business Ethics Quarterly 14(2), 219242 .

P. G. Cassematis and R. Wortley (2013). Prediction of whistleblowing or non-reporting observation: the role of personal and situational factors. Journal Bussines Ethics 117, 615-634 DOI 10.1007/s10551012-1548-3

Ramirez, M. K. (2007). Blowing the whistle on whistleblower protection: A tale of reform versus power. University of Cincinnati Law Review 76, 183-233.

Rhoades, L., \& Eisenberger, R. (2002). Perceived organizational support: a review of the literature. Journal of Applied Psychology, 87(4), 698-714. doi: 610.1037/00219010.1087.1034.1698.

Robertson, J. C., C. M. Stefaniak, and M. B. Curtis. (2011). Does wrongdoer reputation matter? Impact of auditor wrongdoer performance and likeability reputations on fellow auditors' intention to take action and choice of reporting outlet. Behavioral Research in Accounting 23(2), 207-234.

Robinson, S.N., Robertson, J.C., \& Curtis, M.B. (2012). The effects of contextual and wrongdoing attribute on organizational employees' whistleblowing intentions following fraud. Journal of Business Ethics, 106(2), 213-227. doi: 10.1007/s10551-011-0990-y

Rousseau, D. M. (1989). Psychological and implied contracts in organizations. Employee Responsibilities and Rights Journal, 2, 121-139. 
Rousseau, D. M. (1998). The "problem" of the psychological contract considered. Journal of Organizational Behavior, 19, 665-671.

Rothschild, J. (2013). The Fate of Whistleblowers in Nonprofit Organizations. Nonprofit and Voluntary Sector Quarterly, 42(5), 886-901. doi: 10.1177/0899764012472400

Scott, B., Colquitt, J., \& Zapata-Phelan, C. (2007). Justice as a dependent variable: Subordinate charisma as a predictor of interpersonal and informational justice perceptions. Journal of Applied Psychology 92, 1597-1609.

Shanock, L.R. dan Eisenberger, R. (2006). When supervisors feel supported: relationships with subordinates perceived supervisor support, perceived organizational support, and performance. Journal of Applied Psychology, 93 (3), 689-695

Shore, L.M. dan Wayne, S.J. (1993). Employee behavior: and continuance commitment with perceived organizational support. Journal of Applied Psychology, 78 (5), 774- 780

Seifert, D. L., J. T. Sweeney, J. A. Joireman, and J. M. Thornton. 2010. The influence of organizational justice on accountant whistleblowing. Accounting, Organizations and Society $35,707-717$.

Sims, R. L., \& Keenan, J. P. (1998). Predictors of external whistleblowing: organizational and intrapersonal variables. Journal of Business Ethics, 17(4), 411-421. doi: 10.1023/A: 1005763807868

Surat Edaran Mahkamah Agung (SEMA) No. 04 Tahun 2011.

Taylor, E. Z., \& Curtis, M. B. (2013). Whistleblowing in audit firms: organizational response and power distance. Behavioral Research in Accounting, 25(2), 21-43. doi: 10.2308/bria50415

Teo, H. and Caspersz, D. (2011), Dissenting discourse: exploring alternatives to the whistleblowing/silence dichotomy, Journal of Business Ethics 104, 237-249.

Undang-Undang No. 13 Tahun 2006 tentang Perlindungan Saksi dan Korban.

Undang-Undang No. 31 Tahun 1999 tentang Tindak Pidana Korupsi

Vadera, A. K., Aguilera, R. V., \& Caza, B. B. (2009). Making sense of whistle-blowing's antecedents: Learning from research on identity and ethics programs. Business Ethics Quarterly, 19 (4), 553-586. doi: 510.5840/beq200919432.

Valentine, S., Greller, M. M., \& Richtermeyer, S. B. (2006). Employee job response as a function of ethical context and perceived organization support. Journal of Business Research, 59 (5), 582-588. doi: 510.1016/j.jbusres.2005.1006.1004.

Vandekerckhove, W., \& Lewis, D. (2012). The content of whistleblowing procedures: A critical review of recent official guidelines. Journal of Business Ethics, 108, 253-264. 
The Indonesian Journal of Accounting Research - Sep, Vol. 21, No.3, 2018

Wainberg, J., \& Perreault, S. (2016). Whistleblowing in audit firms: do explicit protections from retaliation activate implicit threats of reprisal? Behavioral Research in Accounting, 28(1), 83-93. doi: 10.2308/bria-51122 